\title{
Control of Bacterial Spot of Tomato and Activation of Enzymes Related to Resistance by Chemicals Under Field Conditions
}

\author{
Adriana Terumi Itako ${ }^{1}$, João Batista Tolentino-Júnior ${ }^{1}$, Luis Alfredo Rauer Demant ${ }^{2}$ \\ $\&$ Antonio Carlos Maringoni ${ }^{2}$ \\ ${ }^{1}$ Federal University of Santa Catarina, Curitibanos 89520-000, SC, Brazil \\ ${ }^{2}$ Paulista State University, College of Agricultural Sciences, Department of Plant Protection, CEP 18603-970 \\ Botucatu, SP, Brazil \\ Correspondence: Antonio Carlos Maringoni, Paulista State University, College of Agricultural Sciences, \\ Department of Plant Protection, P. O. Box 237, Botucatu 18603-970, SP, Brazil. Tel: 55-14-3880-7205. E-mail: \\ maringoni@fca.unesp.br
}

Received: February 18, 2014 Accepted: March 12, 2014 Online Published: April 15, 2014

doi:10.5539/jas.v6n5p100 URL: http://dx.doi.org/10.5539/jas.v6n5p100

\begin{abstract}
The control of tomato bacterial spot by the application of chemicals was evaluated on field condition during two trials. Thirty days after transplanting and every 14 days the tomato plants PA-529 hybrid were sprayed with acibenzolar-S-methyl $\left(2.5 \mathrm{~g} \cdot 100 \mathrm{~L}^{-1}\right)$, fluazinam $\left(25 \mathrm{~g} \cdot 100 \mathrm{~L}^{-1}\right)$, pyraclostrobin $\left(8 \mathrm{~g} \cdot 100 \mathrm{~L}^{-1}\right)$, pyraclostrobin + metiram $\left(20 \mathrm{~g} \cdot 100 \mathrm{~L}^{-1}+220 \mathrm{~g} \cdot 100 \mathrm{~L}^{-1}\right)$, copper oxychloride $\left(25.20 \mathrm{~g} \cdot 100 \mathrm{~L}^{-1}\right)$, mancozeb + copper oxychloride $\left(88 \mathrm{~g} \cdot 100 \mathrm{~L}^{-1}+60 \mathrm{~g} \cdot 100 \mathrm{~L}^{-1}\right)$, oxytetracycline $\left(40 \mathrm{~g} \cdot 100 \mathrm{~L}^{-1}\right)$ and water (control), totaling five applications during the crop cycle. Forty days after transplanting, the plants were inoculated with a Xanthomonas perforans isolate $\left(10^{7} \mathrm{UFC} \cdot \mathrm{mL}^{-1}\right)$, disease severity was assessed $(10,19,29$, and 36 days after inoculation), and the area under the disease progress curve was calculated. All chemicals controlled the disease, but better results for total mass and number of fruit was obtained for fluazinam, pyraclostrobin, pyraclostrobin + metiram, copper oxychloride, and mancozeb + copper oxychloride in the first trial, and pyraclostrobin and pyraclostrobin + metiram in the second trial. The average fruit weight, ${ }^{\circ} \mathrm{Brix}, \mathrm{pH}$ and total acidity were not affected by the application of the chemicals. The enzymatic activity of the polyphenol oxidase and peroxidase was higher in the first trial, but in the second, only the polyphenoloxidase had the highest activity in the treatments with acibenzolar-S-methyl, pyraclostrobin, and pyraclostrobin + metiram on tomato leaves. Products containing pyraclostrobin increased the activity of some enzymes without reducing the productivity.
\end{abstract}

Keywords: Solanum lycopersicum, chemical control, enzyme, Xanthomonas perforans

\section{Introduction}

The bacterial spot is considered one of the major diseases of tomatoes. It causes a reduction in productivity by damaging the leaves, causing flowers and fruit to fall prematurely, and by increasing sunburnt fruit (Gitaitis et al., 1992; Vale et al., 2004; Lopes \& Quezado-Duval, 2005). Four species of Xanthomonas are implicated as causal agents of tomato spot: X. euvesicatoria, X. vesicatoria, X. perforans, and X. gardneri (Jones et al., 2004). These species are known to occur in tomatoes in Brazil (Quezado-Duval et al., 2005b; Pereira et al., 2011).

Several preventive strategies are employed in the control of bacterial spot, such as use of healthy seedlings and seed and crop rotation (Lopes \& Quezado-Duval, 2005; Kurozawa \& Pavan, 2005; Silva-Lobo et al., 2005). The chemical control of tomato bacterial spot has been performed with various products, and its success can be attributed to the effectiveness of the products used, the periods and frequency of spraying, and, especially, the sensitivity of the population of Xanthomonas spp. to them (Stall, 1993). Some studies have shown that antibiotics and copper products do not work very well as control agents, and the possible cause of this inefficiency is the selection of resistant strains of Xanthomonas spp. (Marco \& Stall, 1983; Bouzar et al., 1999; Aguiar et al., 2000; Quezado-Duval et al., 2003). Cupric fungicides, antibiotics, and acibenzolar-S-methyl can control tomato bacterial spot on tomato, with the latter being able to induce resistance in plants (Louws et al., 2001; Cavalcanti et al., 2006). However, some reports have shown that production is reduced when acibenzolar-S-methyl is used (Louws et al., 200; Quezado-Duval et al., 2005) due to energy expenditure (Kunh 
\& Pascholati, 2010). Resistance induction, which increases the plant's defenses against a wide spectrum of pathogenic organisms, can be induced by biotic or abiotic agents (Hammerschmidt et al., 1982).

Evidence has been presented on the direct influence of strobilurin on plant physiology (Herms et al., 2002; Köehle et al., 2002). The physiological changes can be positive (Venancio et al., 2005) as they activate biochemical mechanisms that increase plant resistance to pathogens (Herms et al., 2002; Venancio et al., 2003; Venancio et al., 2005; Vigo et al., 2012).

The search for other options to control bacterial spot of tomato has proven a challenge due to the limited availability of effective products. The integration of existing control methods and research involving induction of resistance may contribute to the increased efficiency of strategies to control bacterial spot of tomatoes. The objective of this study was to evaluate the effectiveness of fungicides and one antibiotic to control bacterial spot and to study the induction of enzymes associated with resistance. In order to test the substances, we sprayed them onto tomato hybrid AP-529 in experiments conducted in the field in 2009-2010 and 2010-2011.

\section{Materials and Methods}

\subsection{Field Experiments}

Two experiments were conducted from October to January, one in 2009-2010 and another in 2010-2011. The experiments were conducted in a field located in Botucatu, State of São Paulo, Brazil (latitude: 22 $57^{\prime}$ S, longitude $48^{\circ} 22^{\prime} \mathrm{W}$ ). The Figure 1 show the second experiment. We used PA-529 hybrid, which is characterized by a growth cycle of 110-120 days and pear-type fruit of 80-90 g. Seeds were planted in polystyrene trays filled with commercial substrate, and seedlings were transplanted into the experimental field 30 days after planting.

Each plot was represented by three rows, each $3.00 \mathrm{~m}$ long. The space between the rows was $1.0 \mathrm{~m}$, totaling 9 $\mathrm{m}^{2}$. For the evaluations, we used the center-line of the parcel, which had a working area of $3 \mathrm{~m}^{2}$ and contained 10 plants. The tomato seedlings were transplanted with a line spacing of $0.3 \mathrm{~m}$. The experimental design was a randomized block design with four replications.

Fertilization was performed 7 days before transplanting of the seedlings and subsequently fertilizer was made according Gomes et al. (1999). Other aspects of the cultivation were standard for tomatoes in the region. Sprinkler irrigation was used to meet the water needs of the tomato plants.
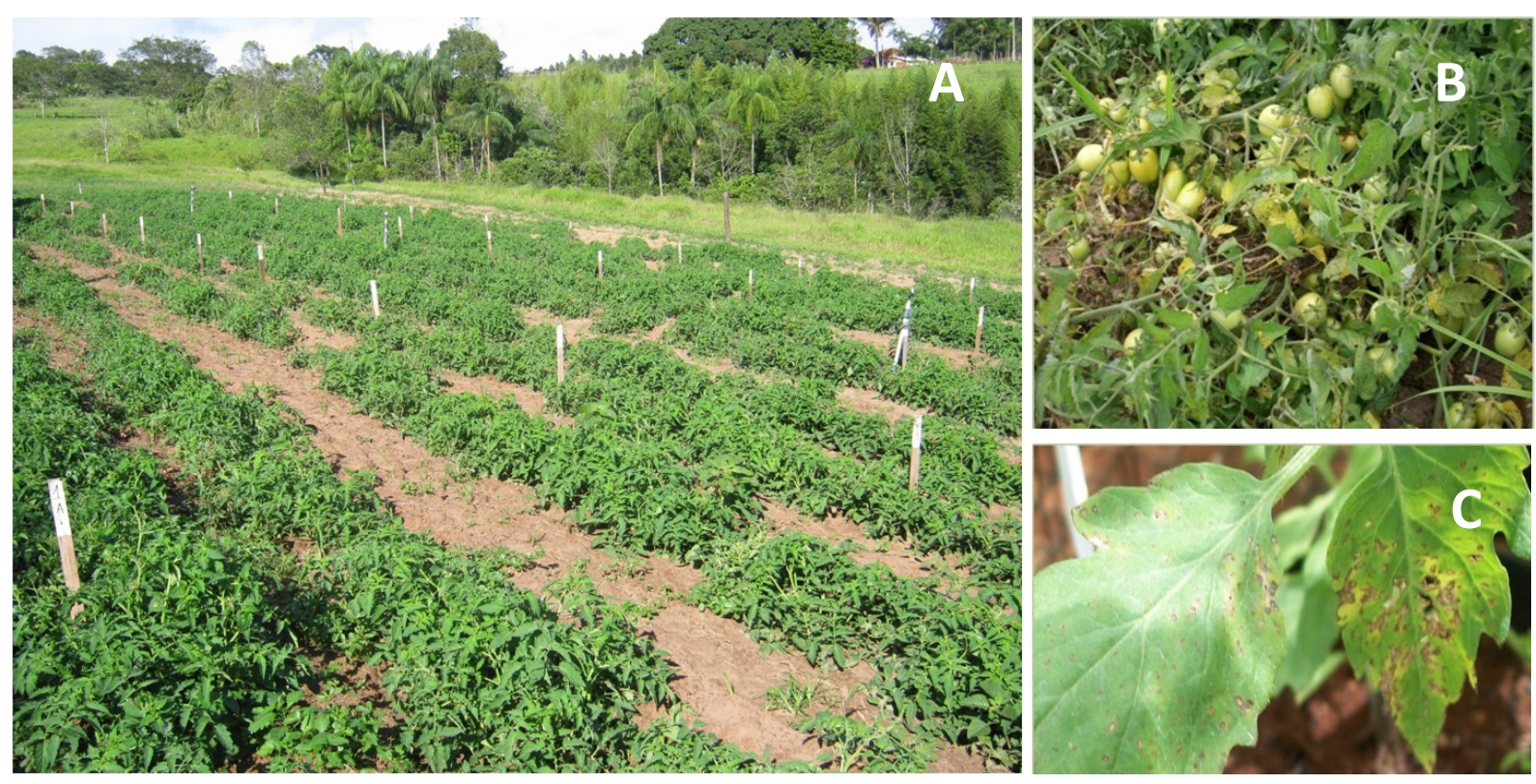

Figure 1. Field experiment conducted from October 2010 to January 2012 with tomato PA-529 hybrid (A), tomato plants on control treatment (B), and typical bacterial spot symptoms on leaflets (C)

\subsection{Chemicals Evaluated in the Control of Bacterial Spot}

The tomato plants were sprayed with acibenzolar-S-methyl $\left(2.5 \mathrm{~g} \cdot 100 \mathrm{~L}^{-1}\right)$, pyraclostrobin + metiram $(20 \mathrm{~g} \cdot 100$ $\left.\mathrm{L}^{-1}+220 \mathrm{~g} \cdot 100 \mathrm{~L}^{-1}\right)$, pyraclostrobin $\left(8 \mathrm{~g} \cdot 100 \mathrm{~L}^{-1}\right)$, copper oxychloride $\left(25.20 \mathrm{~g} \cdot 100 \mathrm{~L}^{-1}\right)$, mancozeb + copper 
oxychloride $\left(88 \mathrm{~g} \cdot 100 \mathrm{~L}^{-1}+60 \mathrm{~g} \cdot 100 \mathrm{~L}^{-1}\right)$, fluazinam $\left(25 \mathrm{~g} \cdot 100 \mathrm{~L}^{-1}\right)$ and oxytetracycline $\left(40 \mathrm{~g} \cdot 100 \mathrm{~L}^{-1}\right) 30$ days after transplanting. The chemical application was performed using a backpack sprayer with a constant $\mathrm{CO}_{2}$ pressure source. The spray volume used varied according to how much was needed to completely wet the aerial portions of the plants.

The products were sprayed every 14 days, totaling five applications during the crop cycle, in addition to weekly spraying with chlorothalonil $\left(150 \mathrm{~g} \cdot 100 \mathrm{~L}^{-1}\right)$ and other insecticides required for pest control (Maringoni et al., 1986). The control treatment involved spraying with chlorothalonil and insecticides only.

\subsection{Assessment of Bacterial Spot}

Isolate Tom-3051 of $X$. perforans (Collection of Plant Pathogenic Bacteria from Plant Protection Department, College o of Agricultural Sciences, Paulista State University, Botucatu, SP, Brazil) was used in the study. The bacteria were cultivated in $500 \mathrm{ml}$ nutrient broth $(5 \mathrm{~g}$ peptone and $3 \mathrm{~g}$ meat extract in $1000 \mathrm{~mL}$ of water) for $24 \mathrm{~h}$ at $28^{\circ} \mathrm{C}$. After this period, the suspension was diluted in the proportion 1:10 in distilled water reaching a final concentration of approximately $10^{7} \mathrm{UFC} \cdot \mathrm{mL}^{-1}$. The spray inoculation was done 40 days after transplanting of the plants, 10 days after the first application of the chemicals.

The disease assessment was carried out on the middle-third of the ten plants at the center-line using the diagrammatic scale developed to evaluate foliar lesions of bacterial spot (Mello et al., 1997). The evaluations were performed at 10,19,29, and 36 days after inoculation (DAI). Using the severity values obtained, the area under the disease progress curve (AUDPC) was calculated as in Campbell and Madden (1990). The AUDPC values were subjected to analysis of variance and their means were compared using the Scott-Knott test at 5\% probability.

\subsection{Harvest and Chemical Analyses of Fruit}

In order to evaluate the tomato yield, fruit were harvested manually, and their total mass $(\mathrm{Kg})$, the number of fruit, and the average weight ( $\mathrm{g}$ ) of each fruit for each plot were determined. The harvest was performed in two stages, the first 90 days after transplanting, and the second up to 105 days after transplanting.

Five fruit were randomly taken from each plot and subjected to chemical analyses ( $\mathrm{pH}$, titratable acidity (TA) and soluble solids ( ${ }^{\circ}$ Brix)) as in the standards of Institute Adolfo Lutz (2008). The results obtained in the evaluations were subjected to analysis of variance, and the means were compared by the Scott-Knott test at $5 \%$ probability.

\subsection{Enzymatic Activity of the Leaves Treated and Inoculated with X. perforans}

In order to evaluate the activity of peroxidase, polyphenol oxidase, $\beta$-1,3-glucanase, phenylalanine ammonia lyase, and protease, leaf samples were collected 5 days before inoculation and 6,15 , and 25 days after inoculation. The leaves were cooled on ice during transport to the laboratory, where they were stored at $-20^{\circ} \mathrm{C}$.

The leaf samples were mechanically homogenized in $4 \mathrm{ml}$ of $100 \mathrm{mM}$ sodium acetate buffer $(\mathrm{pH} 5.0)$. The homogenate was centrifuged at $10000 \mathrm{~g}$ for $25 \mathrm{~min}$ at $4{ }^{\circ} \mathrm{C}$, and the obtained supernatant was considered to be the enzyme extract.

The enzymatic activity of the peroxidase was determined at $30^{\circ} \mathrm{C}$ using a direct spectrophotometric method by measuring the conversion of guaiacol in tetraguaiacol at $470 \mathrm{~nm}$ (Lusso \& Pascholati, 1999). The peroxidase activity results are expressed as specific activity $\left(\Delta_{\text {abs }} 470 \mathrm{~nm} \cdot \mathrm{min}^{-1} \cdot \mu \mathrm{g}^{-1}\right.$ protein).

The polyphenoloxidase activity was obtained by the method of Duangmal \& Apentem (1999), and the results are expressed as $\Delta_{\text {abs }} 420 \mathrm{~nm} \mathrm{~min}^{-1} \mu \mathrm{g}^{-1}$ protein.

The $\beta$-1,3-glucanase activity was determined by the colorimetric quantification of the glucose released from laminarin, through the use of hydrazide $\rho$-hydroxybenzoic acid (PAHBAH) (Lever, 1972). The absorbance of the samples was determined at $410 \mathrm{~nm}$ against the extraction buffer.

The activity of the phenylalanine ammonia-lyase was determined by colorimetric quantification of trans-cinnamic acid released from the substrate phenylalanine (Umesha, 2006). The absorbance readings were plotted on the standard curve for the trans-cinnamic acid and enzymatic activity expressed in $\mu \mathrm{g}$ of trans-cinnamic per min per $\mathrm{mg}$ protein $\left(\mathrm{g} \cdot \mathrm{min}^{-1} \cdot \mathrm{mg}^{-1}\right)$.

The protease activity was obtained in accordance with the methodology used by Fialho (2004). The reading of absorbance was carried out at $280 \mathrm{~nm}$ and the results are expressed as absorbance units per $\mathrm{mg}$ of protein $\left(\mathrm{AU} \cdot \mathrm{mg}^{-1}\right)$.

The quantification of the total proteins present in the extracts was determined using the Bradford method (1976). 
With the results obtained at different times of collection of leaf samples, the area under the progress curve of the production of the compounds was evaluated (enzymes) as a function of time (samples) (Soares et al., 2004). The data were subjected to analysis of variance, using the statistical program SISVAR (Ferreira, 2000) and the means were compared by the Scott-Knott test at $5 \%$ probability.

\section{Results}

\subsection{Severity of Bacterial Spot and Productivity}

The results of the AUDPC obtained in the two tests are shown in Table 1. All products controlled the disease since the values of AUDPC differed and were lower than those observed in the control treatment.

Table 1. Area under the disease progress curve (AUDPC) for the assays conducted in the agricultural years of 2009-2010 and 2010-2011 on tomato hybrid AP-529 inoculated with Xanthomonas perforans

\begin{tabular}{lcc}
\hline \multirow{2}{*}{ Treatment } & \multicolumn{2}{c}{ AUDPC } \\
\cline { 2 - 3 } & $2009-2010$ & $2010-2011$ \\
\hline Acibenzolar-S-methyl & $405.54 \mathrm{~b}^{*}$ & $383.45 \mathrm{~b}$ \\
Pyraclostrobin + metiram & $440.18 \mathrm{~b}$ & $366.36 \mathrm{~b}$ \\
Pyraclostrobin & $447.24 \mathrm{~b}$ & $404.09 \mathrm{~b}$ \\
Copper oxychloride & $499.28 \mathrm{~b}$ & $409.42 \mathrm{~b}$ \\
Mancozeb + copper oxychloride & $432.79 \mathrm{~b}$ & $386.13 \mathrm{~b}$ \\
Fluazinam & $412.48 \mathrm{~b}$ & $435.91 \mathrm{~b}$ \\
Oxytetracyclin & $453.71 \mathrm{~b}$ & $431.24 \mathrm{~b}$ \\
Control & $815.87 \mathrm{a}$ & $716,89 \mathrm{a}$ \\
\hline CV \% & 8.17 & 11.84 \\
\hline
\end{tabular}

*Means followed by the same letters in the column do not differ, based on the Scott-Knott test at $5 \%$ probability.

The values of the total mass of the fruit, fruit number, and average weight of fruit in the two tests are shown in Table 2 and Table 3. In the first trial (Table 2), the products that differed from the control in the total mass and number of fruit were fluazinam, pyraclostrobin, pyraclostrobin + metiram, copper oxychloride, and mancozeb copper oxychloride. In the second trial, for these parameters, only pyraclostrobin, and pyraclostrobin + metiram differed from the control. The average fruit weight was not affected by the application of the chemicals evaluated (Tables 2 and 3 ).

Table 2. Production (Kg/parcel), number, and mean mass ( $\mathrm{g}$ ) of fruit of tomato hybrid AP-529 sprayed with chemical products and inoculated with Xanthomonas perforans in 2009-2010

\begin{tabular}{lccc}
\hline Treatment & Production (Kg/parcel) & Number of fruit & Mean weight of fruit (g) \\
\hline Acibenzolar-S-methyl & $6.27 \mathrm{~b}$ & $87.20 \mathrm{~b}$ & $73.75 \mathrm{a}$ \\
Pyraclostrobin + methiram & $10.76 \mathrm{a}$ & $144.70 \mathrm{a}$ & $74.00 \mathrm{a}$ \\
Pyraclostrobin & $8.36 \mathrm{a}$ & $127.00 \mathrm{a}$ & $67.50 \mathrm{a}$ \\
Copper oxychloride & $9.52 \mathrm{a}$ & $123.70 \mathrm{a}$ & $77.50 \mathrm{a}$ \\
Mancozeb + copper oxychloride & $9.57 \mathrm{a}$ & $133.00 \mathrm{a}$ & $72.50 \mathrm{a}$ \\
Fluazinam & $10.71 \mathrm{a}$ & $135.70 \mathrm{a}$ & $81.00 \mathrm{a}$ \\
Oxytetracyclin & $5.37 \mathrm{~b}$ & $69.50 \mathrm{~b}$ & $78.25 \mathrm{a}$ \\
Control & $4.30 \mathrm{~b}$ & $54.20 \mathrm{~b}$ & $80.75 \mathrm{a}$ \\
\hline CV & 27.37 & 25.98 & 10.49 \\
\hline
\end{tabular}

* Means followed by the same letters in the column do not differ, based on the Scott-Knott test at $5 \%$ probability. 
Table 3. Production, number and mean mass of fruit of tomato hybrid AP-529 sprayed with chemical products and inoculated with Xanthomonas perforans in 2010-2011

\begin{tabular}{lccc}
\hline Treatment & Production $(\mathrm{Kg} /$ parcel) & Number of fruits & Mean weight of fruit (g) \\
\hline Acibenzolar-S-methyl & $12.10 \mathrm{~b}^{*}$ & $260.00 \mathrm{~b}$ & $46.20 \mathrm{a}$ \\
Pyraclostrobin + methiram & $16.70 \mathrm{a}$ & $364.00 \mathrm{a}$ & $46.30 \mathrm{a}$ \\
Pyraclostrobin & $15.70 \mathrm{a}$ & $341.70 \mathrm{a}$ & $45.50 \mathrm{a}$ \\
Copper oxychloride & $11.80 \mathrm{~b}$ & $286.00 \mathrm{~b}$ & $41.50 \mathrm{a}$ \\
Mancozeb + copper oxychloride & $11.10 \mathrm{~b}$ & $237.50 \mathrm{~b}$ & $47.20 \mathrm{a}$ \\
Fluazinam & $10.90 \mathrm{~b}$ & $243.70 \mathrm{~b}$ & $47.80 \mathrm{a}$ \\
Oxytetracyclin & $10.20 \mathrm{~b}$ & $237.70 \mathrm{~b}$ & $42.70 \mathrm{a}$ \\
Control & $10.30 \mathrm{~b}$ & $220.50 \mathrm{~b}$ & $47.00 \mathrm{a}$ \\
\hline CV & 24.63 & 24.00 & 11.22
\end{tabular}

* Means followed by the same letters in the column do not differ, based on the Scott-Knott test at 5\% probability.

\subsection{Chemical Analyses of the Fruit}

The results regarding the analysis of ${ }^{\circ} \mathrm{Brix}, \mathrm{pH}$, and total acidity of the fruit in the two assays are shown in Table 4. These parameters did not differ among treatments, except for the ${ }^{\circ}$ Brix test conducted in 2009-2010, for which the control differed from the other treatments. It should be noted that the coefficient of variation $(\mathrm{CV})$ observed in this analysis was very low (1.04\%) compared to the value obtained in the experiment conducted in 2010-2011, which was $11.42 \%$.

Table 4. Soluble solids ( $\left.{ }^{\circ} \mathrm{Brix}\right), \mathrm{pH}$, and total acidity of tomato hybrid AP-529 sprayed with chemical products and inoculated with Xanthomonas perforans in 2009-2010 and 2010-2011

\begin{tabular}{lcccccc}
\hline \multirow{2}{*}{ Treatment } & \multicolumn{4}{c}{$2009-2010$} & \multicolumn{2}{c}{$2010-2011$} \\
\cline { 2 - 7 } & ${ }^{\circ}$ Brix & $\mathrm{pH}$ & $\begin{array}{c}\text { Total acidity } \\
\text { (mg citric acid /100g) }\end{array}$ & $\begin{array}{c}{ }^{\circ} B r i x \\
\mathrm{pH}\end{array}$ & $\begin{array}{c}\text { Total acidity } \\
\text { (mg citric acid /100g) }\end{array}$ \\
\hline Acibenzolar-S-methyl & $4.14 \mathrm{a}^{*}$ & $4.33 \mathrm{~b}$ & $397.05 \mathrm{a}$ & $5.07 \mathrm{a}$ & $4.04 \mathrm{a}$ & $380.40 \mathrm{a}$ \\
Pyraclostrobin + methiram & $4.14 \mathrm{a}$ & $4.33 \mathrm{~b}$ & $366.31 \mathrm{a}$ & $5.23 \mathrm{a}$ & $3.92 \mathrm{a}$ & $391.33 \mathrm{a}$ \\
Pyraclostrobin & $4.21 \mathrm{a}$ & $4.33 \mathrm{~b}$ & $393.27 \mathrm{a}$ & $5.14 \mathrm{a}$ & $4.01 \mathrm{a}$ & $398.04 \mathrm{a}$ \\
Copper oxychloride & $4.11 \mathrm{a}$ & $4.34 \mathrm{~b}$ & $382.96 \mathrm{a}$ & $5.33 \mathrm{a}$ & $3.90 \mathrm{a}$ & $305.90 \mathrm{a}$ \\
Mancozeb + copper oxychloride & $4.11 \mathrm{a}$ & $4.29 \mathrm{~b}$ & $353.88 \mathrm{a}$ & $5.11 \mathrm{a}$ & $3.89 \mathrm{a}$ & $412.85 \mathrm{a}$ \\
Fluazinam & $4.15 \mathrm{a}$ & $4.34 \mathrm{~b}$ & $381.68 \mathrm{a}$ & $5.33 \mathrm{a}$ & $3.67 \mathrm{a}$ & $379.97 \mathrm{a}$ \\
Oxytetracyclin & $4.08 \mathrm{a}$ & $4.33 \mathrm{~b}$ & $368.81 \mathrm{a}$ & $5.10 \mathrm{a}$ & $4.35 \mathrm{a}$ & $382.53 \mathrm{a}$ \\
Control & $3.84 \mathrm{a}$ & $4.51 \mathrm{a}$ & $338.98 \mathrm{a}$ & $4.85 \mathrm{a}$ & $4.58 \mathrm{a}$ & $347.09 \mathrm{a}$ \\
\hline CV & 7.09 & 1.04 & 15.05 & 4.13 & 11.42 & 18.09 \\
\hline
\end{tabular}

*Means followed by the same letters in the column do not differ, based on the Scott-Knott test at 5\% probability.

\subsection{Enzyme Activity}

The results of enzyme activity are shown in Table 5. The leaves of tomato hybrid AP-529 sprayed with acibenzolar-S-methyl, pyraclostrobin, and pyraclostrobin + metiram, produced more peroxidase in the test of 2009-2010 and polyphenol oxidase in tests of both 2009-2010 and 2010-2011, thus differing from other treatments. There was no increase in the production of phenylalanine ammonia-lyase, $\beta-1,3$-glucanase or protease in the leaves in any treatment evaluated in the two trials. 
Table 5. Enzymatic activity expressed as the area under the progress curve of the production of the compounds evaluated in leaves of hybrid tomato AP-529 sprayed with chemicals and inoculated with Xanthomonas perforans in 2009-2010 and 2010-2011

\begin{tabular}{|c|c|c|c|c|c|}
\hline \multirow[b]{2}{*}{ Treatment } & \multicolumn{5}{|c|}{$2009-2010$} \\
\hline & Peroxidase & $\begin{array}{l}\text { Polyphenol } \\
\text { oxidase }\end{array}$ & $\begin{array}{l}\text { Phenylalanine } \\
\text { ammonia-lyase }\end{array}$ & $\begin{array}{c}\beta-1,3 \\
\text { glucanase }\end{array}$ & Protease \\
\hline Acibenzolar-S-methyl & $170.71 \mathrm{a}^{*}$ & $56.71 \mathrm{a}$ & $8.81 \mathrm{a}$ & $142.76 \mathrm{a}$ & $23.41 \mathrm{a}$ \\
\hline Pyraclostrobin + methiram & $179.61 \mathrm{a}$ & $68.19 \mathrm{a}$ & $9.26 \mathrm{a}$ & $137.60 \mathrm{a}$ & $38.19 \mathrm{a}$ \\
\hline Pyraclostrobin & $179.61 \mathrm{a}$ & $66.84 \mathrm{a}$ & $10.15 \mathrm{a}$ & $147.88 \mathrm{a}$ & $48.19 \mathrm{a}$ \\
\hline Copper oxychloride & $125.90 \mathrm{~b}$ & $29.38 b$ & $10.32 \mathrm{a}$ & $165.27 \mathrm{a}$ & $27.67 \mathrm{a}$ \\
\hline $\begin{array}{l}\text { Mancozeb }+ \text { copper } \\
\text { oxychloride }\end{array}$ & $117.33 \mathrm{~b}$ & $31.09 \mathrm{~b}$ & $11.22 \mathrm{a}$ & $183.45 \mathrm{a}$ & $18.77 \mathrm{a}$ \\
\hline Fluazinam & $148.19 \mathrm{~b}$ & $46.33 \mathrm{~b}$ & $13.07 \mathrm{a}$ & $191.11 \mathrm{a}$ & $26.52 \mathrm{a}$ \\
\hline Oxytetracyclin & $121.90 \mathrm{~b}$ & $31.56 \mathrm{~b}$ & $12.70 \mathrm{a}$ & $213.35 \mathrm{a}$ & $31.56 \mathrm{a}$ \\
\hline Control & $118.20 \mathrm{~b}$ & $33.89 \mathrm{~b}$ & $9.11 \mathrm{a}$ & $220.90 \mathrm{a}$ & $28.89 \mathrm{a}$ \\
\hline $\mathrm{CV}$ & 15.71 & 26.93 & 21.86 & 39.40 & 40.13 \\
\hline \multirow[b]{2}{*}{ Treatment } & \multicolumn{5}{|c|}{$2010-2011$} \\
\hline & Peroxidase & $\begin{array}{c}\text { Polyphenol } \\
\text { oxidase }\end{array}$ & $\begin{array}{l}\text { Phenylalanine } \\
\text { ammonia-lyase }\end{array}$ & $\begin{array}{c}\beta-1,3 \\
\text { glucanase }\end{array}$ & Protease \\
\hline Acibenzolar-S-methyl & $114.90 \mathrm{a}^{*}$ & $33.31 \mathrm{a}$ & $8.20 \mathrm{a}$ & $204.56 \mathrm{a}$ & $48.45 \mathrm{a}$ \\
\hline Pyraclostrobin + methiram & $110.40 \mathrm{a}$ & $31.37 \mathrm{a}$ & $7.84 \mathrm{a}$ & $193.23 \mathrm{a}$ & $49.51 \mathrm{a}$ \\
\hline Pyraclostrobin & $114.11 \mathrm{a}$ & $30.63 \mathrm{a}$ & $10.72 \mathrm{a}$ & $144.50 \mathrm{a}$ & $30.89 \mathrm{a}$ \\
\hline Copper oxychloride & $117.22 \mathrm{a}$ & $21.96 \mathrm{~b}$ & $10.94 \mathrm{a}$ & $136.99 \mathrm{a}$ & $41.63 \mathrm{a}$ \\
\hline $\begin{array}{l}\text { Mancozeb }+ \text { copper } \\
\text { oxychloride }\end{array}$ & $131.11 \mathrm{a}$ & $19.28 \mathrm{~b}$ & $8.26 \mathrm{a}$ & $166.78 \mathrm{a}$ & $37.99 \mathrm{a}$ \\
\hline Fluazinam & $121.88 \mathrm{a}$ & $21.79 \mathrm{~b}$ & $10.32 \mathrm{a}$ & $220.22 \mathrm{a}$ & $45.25 \mathrm{a}$ \\
\hline Oxytetracyclin & $133.21 \mathrm{a}$ & $21.75 \mathrm{~b}$ & $10.15 \mathrm{a}$ & $182.55 \mathrm{a}$ & $34.60 \mathrm{a}$ \\
\hline Control & $130.50 \mathrm{a}$ & $20.89 b$ & $13.94^{\mathrm{a}} \mathrm{a}$ & $145.69 \mathrm{a}$ & $41.58 \mathrm{a}$ \\
\hline $\mathrm{CV}$ & 15.19 & 26.71 & 25.5 & 41.50 & 32.43 \\
\hline
\end{tabular}

* Means followed by the same letters in the column do not differ, based on the Scott-Knott test at $5 \%$ probability.

\section{Discussion}

In Brazil, bacterial spot of tomato is a serious problem because the control of the disease in the field is often not satisfactory. Among the reasons why chemical control is not always effective are the weather, which is favorable to the disease, and the fact that not all populations of Xanthomonas spp. are sensitive to the products used. Acibenzolar-S-methyl, however, is known to be useful in controlling the disease (Louws et al., 2001; Paradela Filho et al., 2001; Quezado-Duval et al., 2005a; Cavalcanti et al., 2006), which was confirmed in the present study.

Unfortunately, the control of bacterial spot with acibenzolar-S-methyl or other products does not always result in higher productivity. This was demonstrated in the two tests conducted here using acibenzolar-S-methyl and oxyetracycline. Our results are consistent with those of Paradela et al. (2001) and Quezado-Duval et al. (2005a) for tomato, and those of Romero et al. (2001) for chili pepper. There is evidence that acibenzolar-S-methyl controls the disease by inducing plant resistance, but the product is implicated in reducing plant productivity (Godard et al., 1999; Dietrich et al., 2005). Plants that allocate their resources to defense against pathogens are 
less productive since the metabolic changes that lead to resistance have a fitness cost associated with them (Iriti \& Faoro, 2003).

The low productivity observed in some treatments is directly reflected in the number of the fruit (Tables 2 and 3). This can be explained by the fact that, in addition to foliar necrosis, which exposes the fruit to sun-burn, the disease can cause stains and decay fruit, as well as causing flowers to fall down (Vale et al., 2004).

The copper-based products and antibiotics are still being regularly used in the field to control bacterial spot. Bacterial sensitivities to antibiotics and/or to copper have been reported in some publications (Marco \& Stall, 1983; Aguiar et al., 2000; Quezado-Duval et al., 2005a). Unlike the results obtained in the present study, Maringoni et al. (1986) tested several copper-based fungicides and antibiotics to control bacterial spot in field conditions using tomato cultivar Agrocica 16. According to their data, the fungicides and antibiotics at the concentrations and applications used did not satisfactorily control the disease. Other parameters were evaluated, such as: number of fruit with symptoms of the disease, number of fruit with sunburn, and total output. They concluded that spraying with copper fungicides did not reduce the leaf area affected by the disease nor did it increase fruit production.

McCarter (1992) obtained satisfactory control of bacterial spot on sweet pepper and increased production with weekly sprays of copper hydroxide + mancozeb. In contrast, the experiments of Carmo et al. (2001) resulted in variable levels of control of bacterial spot on pepper using copper oxychloride.

The success or failure of attempts to chemically control the disease can be partly attributed to a greater or lesser effectiveness of the active ingredients applied, general care, and time of treatments, and especially to the sensitivity of the pathogen population to the products employed (Stall, 1993). Regardless, chemicals continue to be used, firstly because of the lack of alternatives, and, secondly, because they also protect the plants against other pathogens, even when they are not very effective in controlling bacterial spot.

Although the use of fluazinam to control bacterial diseases in plants had not been recorded in the literature, this product reduced the severity of the bacterial spot pathogen on tomato leaves (Table 1) and had a variable effect on fruit production (Tables 2 and 3). Under in vitro conditions, this product had a bactericidal action against $X$. perforans (Itako et al., 2012).

Research on pyraclostrobin-based products was conducted by Nascimento (2009), who evaluated the effect of various chemicals, pulverized on seedlings and in the field, on bacterial spot of the hybrid tomato Heinz 9992 and found that the application of pyraclostrobin + metiram resulted in a good yield.

Regarding the chemical analyses of fruit, the desirable $\mathrm{pH}$ of tomatoes to prevent the proliferation of microorganisms is below 4.5. When the $\mathrm{pH}$ is higher than this, longer periods of sterilization of the raw material through thermal processing are necessary, resulting in higher energy consumption and higher processing costs (Monteiro et al., 2008). In both experiments conducted in the present study, we obtained a $\mathrm{pH}$ value lower than 4.5 in the fruit after the application of chemicals, which provides further evidence on the interference of the disease on this parameter of the fruit (Table 4). Regarding the ${ }^{\circ}$ Brix and total acidity, the application of different chemicals did not affect the control of this fruit parameter (Table 4).

The balance between acidity and sugar is extremely important from the sensory standpoint, because these compounds are mainly responsible for the characteristic flavor of tomato. The sugars of tomato include mainly glucose and fructose (Gould, 1992). The higher the content of soluble solids ( ${ }^{\circ}$ Brix), the greater the yield when it comes to industrial tomatoes and the lower is the energy expended in the pulp concentration processing (Silva \& Giordano, 2000). The average values of ${ }^{\circ} \mathrm{Brix}$ in raw material received by the industries in Brazil have been around $4.5^{\circ}$ Brix (Raupp et al., 2009). The soluble solids in the fruit, besides being a genetic characteristic of the cultivar, are influenced by fertilization, irrigation, and temperature. In tomatoes aimed for industrial processing, bacterial spot can causes a reduction in soluble solids by increased exposure of the fruit to the sun (Lopes \& Quezado-Duval, 2005).

Given the results obtained regarding enzymatic activities, it appears that acibenzolar-S-methyl, pyraclostrobin, and pyraclostrobin + metiram induced the production of peroxidase (Table 5) and polyphenoloxidase (Tables 5 and 6) and these may be involved in the reduction of disease susceptibility (Table 2) as acibenzolar-S-methyl and pyraclostrobin did not inhibit the in vitro growth of $X$. perforans (Itako et al., 2012). No influence on the production of phenylalanine ammonia-lyase, $\beta$-1,3-glucanase, or protease was observed when the other chemicals evaluated were used. Our results partially agree with those of Vigo et al. (2012) on snap-bean plants where spraying acibenzolar-S-methyl and pyraclostrobin resulted in higher levels of polyphenol oxidase, 
peroxidase, and total soluble proteins, suggesting their involvement in the mechanisms of induction of resistance on the common bacterial blight caused by Xanthomonas axonopodis pv. phaseoli.

\section{Acknowledgements}

We are grateful for the financial support of the National Council for the Improvement of Higher Education (CAPES) and the São Paulo Research Foundation (FAPESP).

\section{References}

Aguiar, L., Kimura, O., Castilho, A. M. C., Castilho, K. S. C., Ribeiro, R. L. D., Akiba, F., \& Carmo, M. G. F. (2000). Resistência ao cobre em isolados nacionais de Xanthomonas campestris pv. vesicatoria de pimentão e tomateiro. Agronomia, 34, 78-82.

Bouzar, H., Jones, J. B., Stall, R. E., Louws, F. J., Schneider, M., Rademaker, J. L. W., ... Jackson, L. E. (1999). Multiphasic analysis of Xanthomonas causing bacterial spot disease on tomato and pepper in the Caribbean and Central America: evidence for common lineages within and between countries. Phytopathology, 89, 328-335.

Bradford, M. (1976). A rapid and sensitive method for the quantitation of microgram quantifies of protein utilizing the principle of protein-dye binding. Analytical Biochemistry, 72, 248-254. http://dx.doi.org/10.1016/0003-2697(76)90527-3

Campbell, C. L., \& Madden, L.V. (1990). Introduction to Plant Disease Epidemiology. New York: John Wiley; Sons.

Carmo, M. G. F., Macagnan, D., \& Carvalho, A. O. (2001). Progresso da mancha-bacteriana do pimentão a partir de diferentes níveis iniciais de inóculo e do emprego ou não do controle com oxicloreto de cobre. Horticultura Brasileira, 19, 342-347. http://dx.doi.org/10.1590/S0102-05362001000300011

Cavalcanti, F. R., Resende, M. L. V., Pereira, R. B., Costa, J. C. B. C., \& Carvalho, C. P. S. (2006). Atividades de quitinase e $\beta-1,3$ glucanase após eliciação das defesas do tomateiro contra a mancha-bacteriana. Pesquisa Agropecuaria Brasileira, 41, 1721-1730. http://dx.doi.org/10.1590/S0100-204X2006001200006

Dietrich, R., Ploss, K., \& Heil, M. (2005). Growth responses and fitness cost after induction of pathogen resistance depend on environmental condition. Plant Cell and Environment, 28, 211-222. http://dx.doi.org/10.1111/j.1365-3040.2004.01265.x

Duangmal, K., \& Apenten, R. K. O. (1999). A comparative study of polyphenoloxidases from taro (Colocasia esculenta) and potato (Solanum tuberosum var. romano). Food Chemistry, 64, 351-359. http://dx.doi.org/10.1016/S0308-8146(98)00127-7

Ferreira, D. F. (2000). Sistema de análises de variância para dados balanceados. Lavras: UFLA, 2000. (SISVAR 4. 1. pacote computacional).

Fialho, M. B. (2004). Efeito in vitro de Saccharomyces cerevisiae sobre Guignardia citricarpa, agente causal de pinta preta dos citros. (Mestrado Fitopatologia), Universidade de São Paulo, Piracicaba.

Gitaitis, R., Mccarter, S., \& Jones, J. B. (1992). Disease control in tomato transplants produced in Georgia and Florida. Plant Disease, 7, 651-656.

Godard, J. F., Ziadi, S., Monot, C., Le Corre, D., \& Silué, D. (1999). Benzothiadiazole (BTH) induces resistance in cauliflower (Brassica oleracea var botrytis) to downy mildew of crucifers caused by Peronospora parasitica. Crop Protection, 18, 397-405. http://dx.doi.org/10.1016/S0261-2194(99)00040-X

Gomes, L. A. A., Silva, E. C., \& Faquin, V. (1999). Recomendações de adubação para cultivos em ambiente protegido. In A. C., Ribeiro, P. T. G., Guimarães, \& V. H. Alvarez (Eds.), Recomendações para o uso de corretivos e fertilizantes em Minas Gerais: $5^{\mathrm{a}}$ aproximação. Viçosa - MG: UFV.

Gould, W. A. (1992). Tomato Production, Processing and Technology (3 ed.). Baltimore: CTI Pub. Inc.

Hammerschmidt, T., Nuckles, E. M., \& Kuć, J. (1982). Association of enhanced peroxidase activity with induced systemic resistance of cucumber to Colletotrichum lagenarium. Physiological Plant Pathology, $20,73-82$. http://dx.doi.org/10.1016/0048-4059(82)90025-X

Herms, S., Seehaus, K., Koehle, H., \& Conrath, U. (2002). A strobilurin fungicide enhances the resistance of tobacco against tobacco mosaic virus and Pseudomonas syringae pv tabaci. Plant Physiology, 130, $120-127$.

Instituto Adolfo Lutz. (2008). Normas Analíticas do Instituto Adolfo Lutz. Métodos químicos e físicos para análise de alimentos. Digital. São Paulo: IMESP, v.1. 
Iriti, M., \& Faoro, F. (2003). Benzothiadiazole (BTH) induces cell-death independent resistance in Phaseolus vulgaris against Uromyces appendiculatus. Journal of Phytopathology, 151, 171-180. http://dx.doi.org/10.1046/j.1439-0434.2003.00700.x

Itako, A. T., Tolentino Júnior, J. B., Silva Júnior, T. A. F., Soman, M. J., \& Maringoni, A. C. (2012). Sensibilidade in vitro de Xanthomonas perforans a produtos químicos. Summa Phytopathologica, 38 (supl.), 283.

Jones, J. B., Lacy, G. H., Bouzar, H., Stall, R. E., \& Schaad, N. W. (2004). Reclassification of the Xanthomonads associated with bacterial spot disease of tomato and pepper. Systematic and Applied Microbiology, 27, 755-762. http://dx.doi.org/10.1078/0723202042369884

Köehle, H., Grossmann, K., Jabs, T., Stierl, R., Gerhard, M., Kaiser, W., ... Herms, S. (2002). Physiological effects of the strobilurin fungicide F 500 on plants. In H. Lyr, P. E. Russell, H-W. Dehne, \& H. D. Sisler (Eds.), Modern Fungicides and Antifungal Compounds III. Andover (pp. 61-74).

Kuhn, O. J., \& Pascholati, S. F. (2010). Custo adaptativo da indução de resistência em feijoeiro mediada pela rizobactéria Bacillus cereus ou acibenzolar-S-metil: atividade de enzimas, síntese de fenóis e lignina e biomassa. Summa Phytopathologica, 36, 107-114. http://dx.doi.org/10.1590/S0100-54052010000200001

Kurozawa, C., \& Pavan, M. A. (2005). Doenças do tomateiro (Lycopersicon esculentum Mill.). In H. Kimati, L. Amorim, J. A. M. Rezende, A. Bergamin Filho, \& L. E. A. Camargo (Eds.), Manual de fitopatologia: doenças das plantas cultivadas (4 ed., v. 2, pp. 607-626). São Paulo: Editora Ceres.

Lever, M. (1972). A new reaction for colorimetric determination of carbohydrates. Analytical Biochemistry, 47, 273-279. http://dx.doi.org/10.1016/0003-2697(72)90301-6

Lopes, C. A., \& Quezado-Duval, M. A. (2005). Doenças bacterianas. In C. A. Lopes, \& A. C. Avila (Eds.), Doenças do tomateiro (pp. 62-64). Brasília: EMBRAPA-CNPH.

Louws, F. J., Wilson, M., Campbell, H. L., Cuppels, D. A., Jones, J. B., Shoemaker, P. B., ... Miller, S. A. (2001). Field control of bacterial spot and bacterial speck of tomato using a plant activator. Plant Disease, 85, 481-488. http://dx.doi.org/10.1094/PDIS.2001.85.5.481

Lusso, M. F. G., \& Pascholati, S. F. (1999). Activity and isoenzymatic pattern of soluble peroxidases in maize tissues after mechanical injury or fungal inoculation. Summa Phytopathologica, 25, 244-249.

Marco, G. M., \& Stall, R. E. (1983). Control of bacterial spot of pepper initiated by strains of Xanthomonas campestris pv. vesicatoria that differ in sensitivity to copper. Plant Disease, 67, 779-781.

Maringoni, A. C., Kurozawa, C., Barbosa, V., \& Silva Neto, J. M. (1986). Controle químico da mancha bacteriana (Xanthomonas campestris pv. vsicatoria (Doidge) Dye) do tomateiro (Lycopersicon esculentum Mill.). Summa Phytopathologica, 12, 92-101.

McCarter, S. M. (1992). Effects of bactericide treatments on bacterial spot severity and yield of different pepper genotypes and on populations of certain insects. Plant Disease, 76, 1042-1045.

Mello, S. C. M., Takatsu, A., \& Lopes, C. A. (1997). Escala diagramática para avaliação da mancha-bacteriana do tomateiro. Fitopatologia Brasileira, 22, 447-448.

Monteiro, C. S., Balbi, M. E., Miguel, O. G., Penteado, P. T. P. S., \& Haracemiv, S. M. C. (2008). Nutritional quality the antioxidants of the tomato "Italian type". Alim. Nutr., 19, 25-31.

Nascimento, A. D. R. (2009). Ação de produtos químico in vitro, em mudas e em campo sobre a mancha bacteriana (Xanthomonas perforans e X. gardneri) em tomate para processamento industrial. $126 \mathrm{f}$. (Doutorado em Agronomia: Produção Vegetal). Escola de Agronomia e Engenharia de Alimentos, Universidade Federal de Goiás.

Paradela, A. L., Scachetti, A. P., Munhoz, R., Borim Jr., N., Calafiori, M. H., \& Galli, M. A. (2001). Eficiência de Bion (acibenzolar-S- methyl) como indutor de resistência para o complexo bacteriano (Xanthomonas vesicatoria, Pseudomonas syringae pv tomato e Clavibacter michiganense subsp. michiganense) e insetos vetores de fitoviroses na cultura do tomate (Lycopersicon esculentum L.). Revista Ecossistema, 26, 17-22.

Pereira, R. C., Araújo, E. R., Ferreira, M. A. S. V., \& Quezado-Duval, A. M. (2011). Occurrence of Xanthomonas species causing bacterial spot in fresh market tomato fields in Brazil. Acta Horticulturae, 914, 61-64.

Quezado-Duval, A. M., Gazzoto Filho, A., Leite Júnior, R. P., \& Camargo, L. E. A. (2003). Sensibilidade a cobre, estreptomicina e oxitetraciclina em Xanthomonas spp. associadas à mancha-bacteriana do tomate para 
$\begin{array}{llll}\text { processamento industrial. } \quad \text { Horticultura } & \text { Brasileira, }\end{array}$ http://dx.doi.org/10.1590/S0102-05362003000400020

Quezado-Duval, A. M., Lopes, C. A., \& Junqueira, N. T. V. (2005a). Avaliação de produtos alternativos para o controle da mancha-bacteriana em tomateiro para processamento industrial. Brasília : Embrapa Hortaliças (Boletim de Pesquisa e Desenvolvimento, 14)

Quezado-Duval, A. M., Lopes, C. A., Leite Junior, R. P., Lima, M. F., \& Camargo, L. E. A. (2005b). Diversity of Xanthomonas spp. associated with bacterial spot of processing tomatoes in Brazil. Acta Horticulturae, 695, 101-108.

Raupp, D. S., Gardino, J. R., Schebeski, L. S., Amadeu, C. A., \& Borsato, A. V. (2009). Processamento de tomate $\begin{array}{lllll}\text { seco de diferentes } & \text { cultivares. Acta }\end{array}$ http://dx.doi.org/10.1590/S0044-59672009000200021

Romero, A. M., Kousik, C. S., \& Ritchie, D. F. (2001). Resistance to bacterial spot in bell pepper induced by acibenzolar-S-methyl. Plant Disease, 85, 189-194. http://dx.doi.org/10.1094/PDIS.2001.85.2.189

Silva, J. B. C., \& Giordano, L. B. (2000). Produção mundial e nacional. In J. B. C. Silva, \& L. B. Giordano (Ed.), Tomate para processamento industrial (pp. 8-11). Brasília: Comunicação para transferência de tecnologia/Embrapa Hortaliças.

Silva-Lobo V. L., Giordano, L. B., \& Lopes, C. A. (2005). Herança da resistência à mancha bacteriana em tomateiro. Fitopatologia Brasileira, 30, 343-349. http://dx.doi.org/10.1590/S0100-41582005000400002

Soares, R. M., Maringoni, A. C., \& Lima, G. P. P. (2004). Ineficiência de acibenzolar-S-methyl na indução de resistência de feijoeiro comum à murcha-de-curtobacterium. Fitopatologia Brasileira, 29, 373-377. http://dx.doi.org/10.1590/S0100-41582004000400002

Stall, R. E. (1993). Xanthomonas campestris pv. vesicatoria: cause of bacterial spot of tomato and pepper. In J. G. Swings, \& E. L. L. Civerolo (Eds.), Xanthomonas (pp. 57-60). London: Chapman ; Hall.

Umesha, S. (2006). Phenylalanine ammonia lyase activity in tomato seedlings and its relationship to bacterial canker disease resistance. Phytoparasitica, 34, 68-71.

Vale, F. X. R., Zambolim, L., Zambolim, E. M., \& Alvarenga, M. A. R. (2004). Manejo integrado das doenças do tomateiro: Epidemiologia e Controle. In M. A. R. Alvarenga (Ed.), Tomate: produção em campo, em casa-de-vegetação e em hidroponia (pp. 217-302). Lavras: Editora UFLA.

Venancio, W. S. (2005). Efeitos físiológicos de fungicidas sobre plantas. Revisão Anual de Patologia de Plantas, $13,49-73$

Venancio, W. S., Rodrigues, M. A. T., Begliomini, E., \& Souza, N. L. (2003). Physiological effects of strobilurin fungicides on plants. Publicatio UEPG Ciências Agronômicas e Engenharia, 9, 59-68.

Vigo, S. C., Maringoni, A. C., Camara, R. C., \& Lima, G. P. P. (2012). Evaluation of pyraclostrobin and acibenzolar-S-methyl on common bacterial blight of snap bean. Semina: Ciências Agrárias, 33, 167-174. http://dx.doi.org/10.5433/1679-0359.2012v33n1p167

\section{Copyrights}

Copyright for this article is retained by the author(s), with first publication rights granted to the journal.

This is an open-access article distributed under the terms and conditions of the Creative Commons Attribution license (http://creativecommons.org/licenses/by/3.0/). 